\title{
Environmental vices as ethical and anthropological roots of the environmental crisis*
}

\author{
Wady środowiskowe jako etyczne i antropologiczne źródła kryzysu środowiskowego
}

\section{Dominika Dzwonkowska}

Institute of Ecology and Bioethics, Cardinal Stefan Wyszyński University in Warsaw, Poland

ORCID: https://orcid.org/0000-0002-2060-2901・d.dzwonkowska@uksw.edu.pl

\begin{abstract}
The root of environmental crisis is not only the failure to recognize the intrinsic value of the non-human world, but it can also be perceived as a failure in moral excellence and in the cultivation of virtue. The word "virtue" is an old-fashioned one, representing tradition and today we mostly associate it with academic discussion. However, the term is not only connected with traditional ethical reflection; nowadays, we can witness a revival of virtue discourse in environmental ethics, namely in environmental virtue ethics. The paper analyses the problem of cardinal virtue and vice, and tries to answer which vices are the most responsible for the environmental crisis. Thus the five crucial environmental vices are defined as egoism, greed, arrogance, ignorance and apathy.
\end{abstract}

Keywords: environmental vice, environmental virtue, virtue ethics, environmental ethics, egoism, greed, arrogance, ignorance, apathy

Streszczenie: Źródłem kryzysu środowiskowego jest nie tylko brak uznania wewnętrznej wartości świata poza-ludzkiego, ale również niepowodzenie w kultywowaniu cnoty. Słowo «cnota» jest staromodne i dziś kojarzy nam się głównie z dyskusją akademicką. Jednak termin ten wiąże się nie tylko z tradycyjną refleksją etyczną; dziś jesteśmy świadkami ożywienia dyskursu cnót w etyce środowiskowej i rodzenia się etyki cnót środowiskowych. W artykule analizuje się problem kardynalnych wad i próbuje się odpowiedzieć na pytanie, które z nich są odpowiedzialne za kryzys ekologiczny. W tekście omówiono pięć kluczowych wad środowiskowych: egoizm, chciwość, arogancję, niewiedzę i apatię.

Słowa kluczowe: wady środowiskowe, cnoty środowiskowe, etyka cnót, etyka środowiskowa, egoizm, chciwość, arogancja, niewiedza, apatia

\section{Introduction}

For centuries, philosophers have analysed the condition of man and mankind, defining its main weaknesses. They have also pointed out the virtues to which one has to

\footnotetext{
"This article was originally published in Polish as Dzwonkowska, Dominika. 2014. "Wady środowiskowe jako etyczne i antropologiczne źródła kryzysu środowiskowego." Studia Ecologiae et Bioethicae 12(1): 73-91. The translation of the article into English was financed by the Ministry of Science and Higher Education of the Republic of Poland as part of the activities promoting science - Decision No. 676/P-DUN/2019 of 2 April 2019. Translation made by GROY Translations.
}

strive to achieve moral perfection ${ }^{1}$. Contemporary popular cultural patterns promote behaviours and lifestyles influencing both man and other living beings, as well

\footnotetext{
${ }^{1}$ The term "environmental vices" is not widespread in Polish eco-philosophical literature. However, it is a technical term used in the English-language scientific literature publishing papers on environmental ethics of virtues. The term 'vice' is understood here as a personal trait of man, a personal habit, a quality of the powers of the soul which contributes to moral evil, in this context moral evil refers to those vices which directly or indirectly contribute to the destruction of the environment. The theoretical foundations of the problem of vices and virtues are discussed in more detail in (Dzwonkowska 2013).
} 
as the natural environment as a whole, given the scale of influence increased by technical possibilities. Hence the principle of responsibility (Jonas 1985) which postulates that the increased scale of impact and influence on the environment should be accompanied by increased responsibility for the consequences of our actions (negative responsibility) and for all currently living organisms and the organisms who will live in the future (positive responsibility).

Considering the scale of human technical activities, it is hard not to agree with Jonas. However, the progressing destruction of the environment indicates that a few people seem to notice the problem, and very few seem to be working on solving it. Therefore, why the modern man does not see his obligations towards another man, as well as towards the natural environment? Why does contemporary man, even though being aware of the scale of his actions, rarely takes action to overcome the ecological crisis? Why, being aware of threats, does he take actions that intensify environmental degradation? What is responsible for destroying the environment and what are the ethical and anthropological roots of environmental degradation? These and many other questions arise together with the observation of the progressing destruction of the environment and have become the subject of analyses, in this paper, where an attempt is made to explain the issue by referring to the inside of the man and analysing the so-called environmental vices.

\section{Fundamental environmental vices as a cause of the environmental crisis}

The concept of vice and virtue has a long history in ethics. It was widely discussed in ancient and medieval philosophy, and in later periods was less popular. Currently, these issues are more and more frequently raised in philosophical discussions, and "the ethics of virtues - in its contemporary form, it is most often derived from the postulates formulated by Gertrude Elisabeth Margaret Anscombe, in the classic text Modern Moral Philosophy" of 1958
(Domeracki et al. 2012, 16). The renaissance of discourse on virtues is related to the noticed moral deficiencies of man and the return of the search for answers to urging moral questions in himself. For instance, in the ecophilosophical discourse, the issue of virtues is related to the assumption that the key factor in the moral relationship to environmental problems does not concern human rights or human well-being (Hill 1983, 211), one should not try to seek the reasons for environmental protection through this prism.

According to Hill, the following question should be asked: "What kind of person would do this?" In this paper, the philosopher tells the story of an eccentric rich man who bought a beautiful house in the neighbourhood. The house was surrounded by an amazing garden with a huge avocado tree, flowers and grass. However, since the grass needs to be mowed, the flowers need care, and the man wanted more sunshine, he cut down the tree and the garden was covered with concrete. The story ends with a question: "what kind of person would do this?" Who is the one who underestimates the beauty of nature, and prefers a soulless concrete space? Who do you have to be to make open-pit mines in a big part of the Appalachian mountains? Who do you have to be to destroy the coast redwood habitat in a grove in Santa Cruz County? In each of these examples, nature was destroyed deliberately for the short-term benefit of those who did so. With these questions, Hill shows that the problem of protecting the environment is not a question of proving its intrinsic value or usefulness for people.

Environmental protection is a moral issue, a question of an internal endowment of a man about his inclinations, dispositions and moral skills. In such an approach to the problem, the context of the virtues and environmental vices behind the degradation of the environment is crucial. When analysing the condition of the environment and being inspired by the contemporary discourse on environmental virtues and vices, this paper presents 
a selection of significant human vices that stand behind the destruction of the natural environment. The described vices include egoism, greed, arrogance, ignorance and indifference to environmental issues. Undoubtedly, the list of these vices could be extended by a much longer list of human moral imperfections in the approach to the environment.

\section{Egoism as a cardinal environmental vice}

Egoism is probably the basic and most pernicious vice of modern man. The term means an attitude associated with being guided by one's own good, it is expressed by an excessive interest in one's own and achieving one's goals even at the cost of harming others. As Ingarten points out, "Certainly, egoism dominates most individual, social or national human acts" (Ingarden 1987, 22). Egoism drives the majority of human deeds, weakening human care for the others, the perception of their moral obligations towards the others. Focusing people's attention on themselves, possibly on the circle of their loved ones.

According to Bauman, in post-modernity, we can observe the phenomenon of the so-called subjectivity fetishisation (Bauman 2010, 152). Although, in his opinion, this phenomenon is mainly expressed in satisfying oneself in a continuous consumer rush, undoubtedly, one cannot help but notice a change in the perception of the individual. The modern consumer philosophy is focused on meeting the needs of the individual, on buying products that improve the well-being of the individual and to communicate to others how great one is. Western culture undoubtedly promotes the fetishisation of the individual, in ardent slogans of pursuing one's own needs, taking care of oneself, worshipping individuality and putting oneself first in every relationship one builds. "I" and "my" are the slogans that our contemporaries put on the banners, all their actions are dictated by this message, and the goal of many people's lives is to live for themselves, their lives in which they pursue selfish needs and desires. The analysis of contemporary personal models presented in colour magazines and mass media shows an individual who takes care of himself or herself in the first place and placing concern and interest in others in the following positions.

Egoism also obscures the commitment to the environment. Those who are soaked in this vice have no chance of noticing their obligations towards another person. All the more so nature and its elements cannot become an object of care. On the contrary, when satisfying selfish whims requires that nature be sacrificed, egoism does not allow us to see the evil in this action. It is from egoism that all other vices come, it is egoism that justifies greed and prevents reflection on one's own drives. Egoism is also the foundation of arrogance and indifference, it justifies the lack of need to take care of others and notice the obligations to the environment. Also, ignorance finds egoism a powerful ally and supporter - why should a man want to deepen his knowledge of the environment and ways of protecting it if such knowledge could be detrimental to fulfilment of his desires with a clear conscience? Egoism creates a veil that separates "I" and "my" from the world and focuses all drives, feelings, and thoughts around oneself. Egoism is a solid foundation and the father of greed, the second key environmental vice.

\section{Greed as a cardinal environmental vice}

For centuries, man has been striving to constantly improve his fate by acquiring new material goods and multiplying his wealth. For many people, this has become the cause of an excessive desire for possessing material goods and a path to greed. Aristotle defines "greed" as a characteristic ascribed to those who care for material goods more than they should (Arystoteles 2007, 119b), the essence of greed consists in "insufficient generosity and excessive desire to take, which do not occur together in all of them, but sometimes separately" (Arystoteles 2007, 121b). Greed as an environmental vice is related to the latter disposition, it is associated with a constant desire to have more than is necessary to 
satisfy the basic life needs. Greed contains an element of continuous dissatisfaction, and thus a continuous desire to have more and more. As Bauman notes, a contemporary man in a constant hurry does not buy things to own them but to get rid of them constantly and replace them with new ones. "In (...) the life of an ardent consumer, the new Erlebnisse the reason to hurry is not to buy and collect, but to dispose of and replace" (Bauman 2010, 208). Each newly purchased thing satisfies our need to possess only for a moment to give way to the desire to have a different thing, which is fervently used by marketing specialists to create new needs and arousing the consumers' desire to have things they have not even known that existed before. Every new product that arouses our interest is removed from our lives equally quickly, giving way to another "essential" good.

"In the 'casino culture', as George Steiner called it, every cultural product is supposed to have as much impact as possible (that is to depreciate and displace yesterday's cultural products from the market) and be immediately usable (reduce the distance between a store shelf and a waste bin, i.e. the reluctance to abuse consumer hospitality, quick removal from the stage to free up space for cultural products of tomorrow)" (Bauman 2010, 227).

Greed is expressed in consumerism, which has become the dominant cultural model of today, efficiently fuelled by clever marketing that evokes new needs in us. Cafaro defines greed as a trait that makes us egoists to the greatest extent (Cafaro 2005, 147). Greed both makes us selfish and grows out of egoism, strengthening it. Aristotle stressed that greed leads to attempts to enrich oneself by hurting others and that a greedy person often benefits from cheating on friends whom he should support (Arystoteles 2007, 122a). However, the hurt friends moving away is not the only reason why greed distances us from others, the very nature of consumption is, in fact, based on alienation, consumption is an archetype of loneliness and distances people from others. Consumption "is a kind of activity that is carried out in total solitude (...) even if it is supposed to take place in the company of other people. No lasting ties are created in it. Those that may arise from an act of consumption have no chance of surviving a long time" (Bauman 2010, 184). Therefore, homo consumens will strive to realise his own rapacity and intemperance by permanent striving for more than he needs, and sometimes more than he can ever use. The problem with the consumer lifestyle model is that we increasingly tend to value things for being a carrier of the value they are assigned to, not for their functionality. In such an approach, material goods are not valuable because they are useful but because they are elements of prestige and comfort (Baudrillard 1998, 76; Kennedy 2007, XV and XVI). Hereby, things detached from their functionality and actual material value become symbols of the social position of the consumer, who, seeking to constantly emphasise his material status, succumbs to new temptations to have ever better symbols of his "perfection".

While temperance indicates submission to reason and prudence in one's choices (Pańpuch 2001), greed excludes submission to reason and. consequently, can lead to submission to desires and an escalation of growing needs. Submission to lust is a sign of weakness of will and domination of lustful powers over cognitive powers. A greedy man is a slave to his own body and remains unsatisfied all the time, he does not enjoy the pleasures but still wants more. Lenience to one's senses brings the person to the path of deprivation where one can never find fulfilment "in a society that is not too poor, water and bread are rarely lacking. In the richest society - there is always too little gold or luxury" (Comte-Sponville 2000, 42). Greed pushes into the claws of consumerism. Taking into account the effects of consumptionism and its impact both on the individual and his or her environment, and on the entire natural environment, it should be subject to moral reflection and become the subject of ethical analysis. Consumerism is one of 
the greatest moral challenges of current times, the thoughtless use and the waste of resources has today become a cultural entertainment and hobby for hundreds of thousands of people in Western societies. King classifies consumerism as one of the "environmentally dysfunctional beliefs and practices" (King 2006, 174) and "an environmentally destructive habit” (King 2006, 174). The scale of the environmental impact of the unlimited waste of resources is terrifying, but unfortunately, it is not known or justified in the consciences of consumers.

\section{Arrogance as a cardinal environmental vice}

Dealing with consumerism is not an easy task as there is another environmental drawback on its way, arrogance. Arrogance, pride and humility are virtues and vices to which much thought has been given. Christianity sees pride and arrogance as one of the main vices that cause our evil deeds and keep us away from God. Modesty and humility are the craved virtues which assume not to exalt oneself and not to appear before others. In Christianity, they refer to the relationship with God, considered to be the source of all good. In philosophy, it is the source of virtues and righteous conduct. For instance, the Stoics perceived modesty as a trait of a sage who is indifferent to both fame and lack of it (Diogenes Laertios 1982, 416). Modesty, in their opinion, results from moderation, which is in contradiction with the above-mentioned vice.

However, modern culture rejects modesty and humility as traits standing in the way of the realisation of modern man. Modern man puts himself and his good above the good of the entire earth's ecosystem. Contemporary man often tends to perceive nature only as a resource of endless goods for himself. Resources that he can use according to his needs, according to his whims. Such an attitude results mainly from abuse and misunderstanding of man's privileged position in the natural world, which is reflected in anthropocentrism. Anthropocentrism allowed us to legitimise the conviction that man is su- perior to the natural environment. Hence, some people even use terms such as species chauvinism to describe man's attitude towards the environment and its elements (Singer 2004).

Anthropocentrism ${ }^{2}$ is derived from the

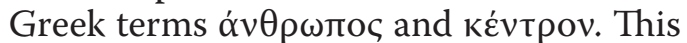
is a view that man is the centre of the world, everything in nature happens because of him and is only confirms his privileged position. According to anthropocentrism, only man is an entity fully deserving of being assigned a value, and the value of other beings can be assessed at most in terms of their suitability for human purposes. Anthropocentrism is the realisation of man's haughtiness and pride and the sanctioning of the view of man's superiority over the whole animated world. It is an excuse to treat nature and its resources only as raw material and a tool for achieving one's own goals, not always related to meeting the basic needs.

Anthropocentrism is closely related to egoism because it does not mean the care for the good of humanity as a whole or a given community. In the post-modern era, it evolved from the care for a group of people to the care for "I" and "my". It is the approbation of my own imperfection, of my rights and an expression of concern for my well-being, it is an expression of arrogance and puts man above everything and everyone. Today's anthropocentrism has both contributed to the degradation of the environment and made people justify their actions harmful to the environment, without perceiving them as inappropriate. It has become an excuse for conditioned moral blindness which allows for acts that are detrimental to the environment as long as they serve to satisfy the needs of the human being, not necessarily only the basic needs critical for survival.

${ }^{2}$ When the 1967 Lynn White's article "The Historical Roots of Our Ecologic Crisis." Science 155(3767): 1203-1207. Judeo-Christian religions were blamed for this attitude. White sharply criticised the despotic domination of man over other beings established by the second most anthropocentric religion in the world (rights after Zoroastrianism). 
The anthropocentric attitude can be seen in every human action, even often in those actions that are intended to protect the environment or to draw attention to its value. Valuation of ecosystem services is one example here. The idea itself is based on the conviction that ecosystem services are not elements of the natural human-environmental relationship, but they are more of a master-slave relationship (Peterson 2012, 5; Plumwood 2001, 20). The concept of ecosystem services is based on the conviction that the environment is only a provider of "services", "benefits" to people. This "servant" function is reflected in the name these are not just phenomena occurring in the ecosystem but services or benefits. The English word services, which has the same core as the word "slave",'servant" in English (servant) and Latin (servus). In this sense, the environment and its elements only have value to the extent they are being used by a man. The environment is not a value in itself, and calculating the costs of ecosystem services is not intended to realise the value of nature but to evaluate the costs of services. Unfortunately, this type of relationship shows the anthropocentric and economic attitude of man to the environment and its resources. Peterson $(2012,3)$ points out that reversing this relationship would jeopardize the concept of using natural resources, and thus human interests.

Anthropocentrism is the justification and foundation of man's arrogance, the justification for man's control over nature and the justification for destroying it if nature is to serve human goals. This results in the thoughtless exploitation of natural resources to meet temporary, fleeting needs and desires, without thinking about the long-term effects of these actions. Human arrogance manifests itself in various ways, one of the more harmful examples being the belief in the unlimited possibilities of controlling nature, expressed by practical attempts to subordinate it with the help of science and technology. The belief in the possibilities of technology dates back to the times of Bacon, who expressed with his statement ipsa scientia potestas est his conviction that it is necessary to use scientific achievements in practice and to support science for practical purposes ${ }^{3}$. This view was strengthened in the subsequent period, and numerous achievements of the scientific and technical revolution contributed to its strengthening and legitimacy. This provides a basis for developing uncontrolled technical activity. Currently, the scale of the impact of the current technical activities poses a real threat to the integrity of the natural environment and human life. As a result, technology loses its axiological neutrality and leads to questions about the far-reaching effects of technical activities.

For instance, geoengineering is a disturbing phenomenon that seems to reveal the arrogance of man and his belief in the unlimited possibilities of taking control over nature using technology. Geoengineering is a set of large-scale projects aimed at combating climate change by reducing the amount of carbon dioxide in the atmosphere or changing albedo. These projects attempt to prevent climate change in a different way than by limiting the scale of interference and technical activity or by using less intrusive and more environmentally friendly technologies. Geoengineering is based on the belief that a set of technologies has indeed been invented that will contribute to reducing environmental degradation through even more advanced interference. This type of attitude best expresses human trust in technology and the conviction about the possibility of influencing the environment through its use. It is an expression of human arrogance and a dangerous attitude that may both fail to bring the expected results and lead to deeper degradation of the Earth ecosystem.

\section{Ignorance as a cardinal environmental vice}

An arrogance that becomes legitimate in the conviction of the superiority of man over other species and the resulting right

\footnotetext{
${ }^{3}$ More on the transformation of the approach to knowledge and science can be found, for instance, in Dzwonkowska, Dominika. 2011. „Pozytywistyczne ujęcie relacji filozofii do nauk przyrodniczych.” Studia Philosophiae Christianae 47(2): 199-212.
} 
to unlimited management of resources is an extremely dangerous environmental vice. Combined with another vice, ignorance, it becomes a significant threat to the integrity of the natural environment. The word 'ignorance' comes from the Latin ignorantia meaning unawareness, which is an expression of lack of knowledge, lack of awareness, and unwillingness to deepen one's knowledge.

In terms of environmental protection, it seems to be particularly dangerous, as any actions in this area have to be based on thorough knowledge and prudence in its use to be effective. The problem of ignorance as a threat to ethical action was pointed out by Socrates, who perceived ignorance as the main reason for inappropriate actions. In his opinion, the knowledge of what to do and how to act was the cause of righteous action and helped people pursue their virtues in everyday life and to face the ethical challenges that stood in their way. This belief was widespread in ancient times and also appears in the thought of other philosophers. For instance, Heraclitus of Ephesus claimed that people "are driven by greed and lust for fame because of shameful ignorance" (Laertios 1982, 515). Knowledge was perceived as a good that helps one live according to virtues and recognise what is important and worthwhile in life, and ignorance as an obstacle to one's own moral perfection, which has often pushed people to get involved in things that are poor and trivial, such as fame, power or wealth. Knowledge has become a tool for distinguishing between what is transitory and gives a momentary satisfaction of the senses or flattering of one's own vanity, and what is important and has a real meaning in the life of a man striving for moral perfection. Ignorance is an obstacle to a person's personal development, because the person guided by it errs, unaware of what is good and what is bad. Ignorance deceives him and obscures the distinction that can help him act morally.

The problem of ignorance in the context of environmental concerns arises in two dimensions at least. First of all, as the lack of knowledge that activities that affect the environment can be considered in terms of moral good and evil, second of all, there is the problem of identifying which actions affect the environment, how and to what extent. In the case of the first type of ignorance, environmental ethics is of key importance, which (influenced by the perception of the ethical dimension of the relationship human-the environment) attempts to "restore the relationship of man to the environment" (Sylvan 2005, 24) and show the moral obligations of man towards nature. Environmental ethics tries to show to Western civilization that care for the environment and other living organisms is an object of ethical concern, and that any omissions in this matter are treated as a moral evil in environmental ethics.

Environmental ethics makes us aware of the problem of environmental degradation and our responsibility for it. It is an example of specific ethics with the human impact on the natural environment as its material subject. Environmental ethics attempts to secure the interests of present and future generations by taking into account the sustainability of resources, species and ecosystems. In this discipline, a whole range of specific problems can be noticed. These problems raise many issues relevant to the relationship between man and the environment. Environmental ethics presented in this way draws attention to the moral obligations of man towards the natural environment, showing that the ethos goes beyond the anthropocentric boundaries. Environmental ethics allows for "significant enriching the disciplines involved in environmental protection with a significant element - axiological and educational dimension" (Tyburski 2013, 103), thus playing a key role in environmental protection.

The second approach to ignorance refers to the intellectual sphere to a slightly different extent - the problem occurs when an active entity is aware of its obligations to the natural environment but is not fully aware of what action should be taken to counteract environmental degradation 
or, as a result of lack of knowledge, takes inappropriate action, achieving an effect that is different from the assumed one. This problem results from the complexity of the Earth's ecosystem and the numerous interrelationship and interactions in various areas of the Earth's ecosystem, and also leads to ignorance when associated with a reluctance to understand the complexity of the Earth's ecosystem. Ignorance results from not making an effort to understand what needs to be done to protect the environment in a proper way. A faultless lack of knowledge in this respect is not negligence and cannot be treated as a vice. Conscious avoidance of broadening one's knowledge and the fact that one is stuck in ignorance is a vice.

Breaking the ignorance requires an intellectual effort directed to learning the essence of a given phenomenon and choosing the best means of action requires the practical implementation of the traditionally understood virtue of prudence. It is not an easy action. As a result of the multitude of impacts, it is often difficult to identify actions that will solve the problem. The analyses of Donella H. Meadows and Dennis L. Meadows are an interesting example of searching for solutions to the problem of complexity and connections of the Earth's ecosystem and the related difficulty of acting in the face of environmental problems. When the UN Secretary-General $U$ Thant presented a report on the contemporary problems in 1969, the key elements mentioned by him included, for instance, the degradation of agricultural land, chaotic urban development, loss of biodiversity, environmental pollution, protection of soil, water and the atmosphere, and the need to consider the environment when developing new technologies. Moved by the contents of this report, the Meadows couple and other members of the Club of Rome, undertook analyses of the state of affairs using the methodology of systemic thinking. They tried to find a common thread of the problems mentioned above, which, if changed, would solve them. As the unifying plane of the aforementioned problems, they pointed to development, postulating a paradigm shift in development from exponential to sustainable development. Reflection of their analyses and concern for the implementation of sustainable development can be found, inter alia, in the reports of the Club of Rome, updated many times.

Unfortunately, any interference with the environment, even those that are used to solve an environmental problem are subject to risk. Despite thorough prior analysis and preliminary research, it is difficult to predict all the side effects of a given action, and numerous environmental disasters seem to confirm this state of affairs. Due to this complexity of the ecosystem and our ignorance of how to protect it, ignorance becomes one of the most dangerous environmental vices, posing a significant threat to the state of the environment.

\section{Indifference as a cardinal environmental vice}

Ignorance results from indifference, which is associated with a total lack of interest in the problem of environmental degradation. Indifference results from the conscious avoidance of seeing the problem of environmental degradation as related to our moral obligations, and thus involves an attempt to avoid the pursuit of moral norms relating to our relationship with the environment.

Indifference is a symptom of a lack of feelings, a lack of any internal excitement concerning a given matter, and is linked to the Greek $\bigotimes \pi \alpha \dot{\theta} \theta \varepsilon ı \alpha$, which means a state associated with a lack of suffering and passion. Such a state was desired in Stoic philosophy and meant the achievement of philosophical wisdom and an inner state that cannot be touched by the down-to-earth and fleeting matters of the temporal world. According to the Stoics, a philosopher who is directed towards higher goals is neither susceptible to excessive joy nor doubts because of any failure. He accepts all events with due calmness and composure. The feature that was desired by the Stoics is seen by Cafaro in a slightly different way as combined with discouragement and laziness. He perceives it as a manifestation of passivity towards the 
phenomenon of progressive degradation of the natural environment, with effects that may have a colossal impact on the Earth's ecosystem.

Regardless of the feeling of apathy, both in the positive sense (according to the Stoics) and in the negative sense as discouragement, indifference is an environmental vice expressed in the lack of interest in the problem of environmental degradation. Indifference does not allow for the realisation of environmental virtues and for undertaking a moral commitment to care for the natural environment. Responsibility for the environment postulated by Jonas faces silence and indifference on the part of those who see the need to take action. Responsibility in almost all European languages is associated with the term "response", which means that noticing a need gives rise in the moral subject to the need to "respond" to that need. Noticing that the environment is being destroyed and degraded should trigger the need to react to this state and remedy it. Unfortunately, in the case of indifference it faces a lack of reaction, a deliberate failure to take action to protect the environment, and even a failure to stop activities destroying the environment.

The environment is only perceived as a source of resources that can be used for other purposes, it is not considered to be a value itself. Hence the moral deficit associated with indifference to environmental issues. It is only when we understand that the environment and its resources are an autotelic value, and that their condition depends on our care for them, that we can overcome our indifference and contribute to taking the environment into account in moral choices. Indifference, along with greed, arrogance, and ignorance, constitute cardinal environmental vices that are an obstacle to fulfilling our moral obligations to the natural environment.

\section{Conclusions}

Contemporary environmental discourse in philosophy and culture is rooted in the times of American transcendentalism when the topic of concern for nature appeared in literature and began to shift gradually to culture. Although decades passed, the problem of approach to the environment still raises many doubts, and man's attitude towards the environment often does not go beyond an anthropocentric orientation. The paper assumes that the reason for the lack of change lies in man, has a direct source in the traits of his character, his disposition and will, which manifests itself as environmental vices. Environmental vices contribute to the failure to notice or ignore the problems of degradation of the natural environment and to obscuring cognitive authorities, which makes it impossible for people to properly assess their obligations towards the environment. Our anti-environmental behaviour result from deficits in character, from defects that make man fail to take into account the care of the natural environment. There may be numerous environmental vices, and several of them, which were identified as crucial, were referred to in the paper. Taking into account the scale of their impact and the consequences of their disastrous influence on our actions, the paper describes the vices considered to be most harmful, namely: egoism, greed, arrogance, ignorance and indifference.

This paper is an outline of the issues and a certain attempt to present the ethical and anthropological sources of the environmental crisis in the form of a discourse on environmental virtues and vices. Each of these vices is only brought closer and described very briefly by pointing out its causes, conditions and its influence on the degradation of the natural environment. The framework of the article only allowed for outlining the issue and for opening a space for a wider discussion on environmental vices or their individual aspects. Moreover, the discussion on environmental vices should be complemented by a discussion on environmental virtues or by the dynamically developing ethics of environmental virtues. Each of the above-mentioned vices corresponds to a virtue to be cultivated. Care for others, expansion of the circle of those we solicit, care for, those 
we love, the shift from me to others is the virtue that counterbalances egoism. Greed should be counterbalanced by moderation, arrogance - by respect, ignorance - by wisdom, indifference - by responsibility.

\section{Bibliography}

Arystoteles. 2007. Etyka Nikomachejska. Warszawa: Wydawnictwo PWN.

Baudrillard, Jean. 1998. The Consumer Society. London: Sage.

Bauman, Zygmunt. 2010. Szanse etyki $w$ zglobalizowanym świecie. Kraków: Znak.

Birch, Thomas H. 1993. "Moral Considerability and Universal Consideration." Environmental Ethics 15(4): 313-332.

Cafaro, Philip. 2005. "Gluttony, arrogance, greed and apathy: an exploration of environmental vice." In: Environmental Virtue ethics, edited by Ronald Sandler, Philip Cafaro, 135158. Oxford: Oxford University Press.

Comte-Sponville, André. 2000. Maty traktat o wielkich cnotach. Warszawa: Oficyna Wydawnicza Volumen.

Domeracki, Piotr, Marcin Jaranowski, and Marcin T. Zdrenka. 2012. Szesś́ cnót mniejszych. Toruń: Wydawnictwo Naukowe UMK.

Dzwonkowska, Dominika. 2013. "Virtue and Vice in Environmental Discourse." Studia Ecologiae et Bioethicae 11(4): 61-76.

Hill, Thomas E. Jr. 1983. "Ideals of Human Excellence and Preserving Natural Environment." Environmental Ethics 5(3): 211-224.

Ingarten, Roman. 1987. Ksiażeczka o człowie$k u$. Kraków: Wydawnictwo Literackie.
Jonas, Hans. 1985. The Imperative of Responsibility: In Search of an Ethics for the Technological Age. Chicago: Chicago University Press.

Kennedy, Greg. 2007. An ontology of trash. Albany: State University of New York Press.

King, Roger H. 2006. "Playing with Boundaries: Critical Reflections on Strategies for an Environmental Culture and the Promise of Civic Environmentalism." Ethics, Place, and Environment 9(2): 173-186.

Laertios, Diogenes. 1982. Żywoty i poglądy słynnych filozofów. Warszawa: Wydawnictwo PWN.

Pańpuch, Zbigniew. 2001. „Cnoty i wady." W Powszechna Encyklopedia Filozofii, vol. 2, red. Andrzej Maryniarczyk et al., 216-231. Lublin: Polskie Towarzystwo Tomasza z Akwinu.

Peterson, Keith. 2012. "Ecosystem Services, Nonhuman Agencies, and Diffuse Dependence." Environmental Philosophy 9(2): 1-19.

Plumwood, Val. 2001. "Nature as Agency and the Prospects for a Progressive Naturalism." Capitalism, Nature, Socialism 12(4): 3-32.

Singer, Peter. 2004. Wyzwolenie zwierzat. Warszawa: PIW.

Sylvan, Richard. 2005. "Is there a Need for a New, an Environmental, Ethics?" In Environmental Philosophy. Critical Concepts in the Environment, vol. 1, edited by J. Baid Callicot, Clare Palmer, 205-210. New York: Routledge.

Tyburski, Włodzimierz. 2013. Dyscypliny humanistyczne i ekologia. Toruń: Wydawnictwo Naukowe UMK. 